\title{
Survivin: a unique target for tumor therapy
}

\author{
Himani Garg ${ }^{1}$, Prerna Suri ${ }^{2}$ Jagdish C. Gupta ${ }^{3}$, G. P. Talwar ${ }^{3}$ and Shweta Dubey ${ }^{\text {* }}$
}

\begin{abstract}
Survivin is the smallest member of the Inhibitor of apoptosis (IAP) family of proteins, involved in inhibition of apoptosis and regulation of cell cycle. These functional attributes make Survivin a unique protein exhibiting divergent functions i.e. regulating cell proliferation and cell death. Expression pattern of Survivin is also distinctive; it is prominently expressed during embryonal development, absent in most normal, terminally differentiated tissues but upregulated in a variety of human cancers. Expression of Survivin in tumours correlates with not only inhibition of apoptosis and a decreased rate of cell death, but also resistance to chemotherapy and aggressiveness of tumours. Therefore, Survivin is an important target for cancer vaccines and therapeutics. Survivin has also been found to be prominently expressed on both human and embryonic stem cells and many somatic stem cell types indicating its yet unexplored role in stem cell generation and maintenance. Overall, Survivin emerges as a molecule with much wider role in cellular homeostasis. This review will discuss various aspects of Survivin biology and its role in regulation of apoptosis, cell division, chemo-resistance and tumour progression. Various molecular and immunotherapeutic approaches targeting Survivin will also be discussed.
\end{abstract}

Keywords: Survivin, Immunotherapy, Apoptosis, IAPs

\section{Background}

Cancer is a heterogeneous group of diseases where abnormal cell growth with potential to invade other body parts takes control of normal homeostasis and becomes fatal if not timely and rightly treated. While standard treatments like surgery, chemotherapy or radiotherapy have significantly improved the disease outcome, occurrence of drug resistance and metastatic spread of the disease still remains a tough challenge. Substantial data suggests that immunotherapy could serve as a powerful weapon to prevent metastatic spread of cancer. Immunotherapy specifically targets tumor cells thereby avoiding collateral damage to non-tumor cells. Induction of anti-tumor response also has the potential to eradicate tumor at distant sites in the body which may not be possible by surgical resection. Induction or enhancement of anti-tumor immune response is a formidable challenge in

\footnotetext{
*Correspondence: sdubey@amity.edu

${ }^{1}$ Amity Institute of Virology and Immunology, Amity University Uttar Pradesh, J-3 Block, Room No: LG21, Sector 125, Noida, Uttar Pradesh 201303, India

Full list of author information is available at the end of the article
}

cancer because tumor cells use multiple evasion strategies and avoid being detected or eliminated by immune cells. Resistance to apoptosis is one important evasion mechanism by which tumour cells escape detection by immune cells and promote their proliferation at the same time. Therefore, molecules involved in regulation of apoptosis can be potential targets for tumor therapy including immunotherapy.

Inhibitor of apoptosis protein family (IAPs) is an important group of proteins involved in regulation of apoptosis. IAPs also have an important role in regulation of $\mathrm{T}$ cell responses in anti-tumor immunity. One member of this protein family, Survivin occupies a key position because of overexpression in cancer cells. It is speculated that Survivin overexpression in tumor cells promotes tumor progression by multiple pathways such as dysregulation of apoptosis and cell division, altered sensitivity to antitumor drugs or promoting survival of cancer stem cells. Survivin can serve as a universal tumor antigen because it is expressed in most human malignancies and has the potential to trigger immune effector responses. Therefore, blocking Survivin function by 
various immunotherapeutic or molecular approaches is emerging as a promising therapeutic strategy in cancer. This review will discuss various aspects of Survivin biology and multiple approaches to block Survivin in tumor cells.

\section{IAP family and Survivin}

Inhibitors of apoptosis (IAP) family of proteins are found in almost all species from lower to higher vertebrates. Initially identified in baculoviruses as apoptotic suppressors, eight IAP homologs namely neuronal apoptosis inhibitory protein (NAIP), baculoviral IAP repeat-containing protein 2 /human inhibitor of apoptosis protein-2 (c-IAP1/HIAP-2), baculoviral IAP repeat-containing protein3/human inhibitor of apoptosis protein-1 (c-IAP2/ HIAP-1), X-linked inhibitor of apoptosis (XIAP), IAPlike protein 2 (ILP2), melanoma inhibitor of apoptosis protein (MLIAP), Survivin, and BIR repeat-containing ubiquitin enzyme system (BRUCE) have been identified in humans till date [1-10]. IAPs are functionally and structurally similar and function in regulation of programmed cell death [11-13]. Since IAPs are an important protein family which regulate cell fate in response to stress signals or genomic instability, therefore any dysregulation in IAP function has an obvious association with cancer development, induction of oncogenesis or drug resistance [14]. Investigating the mechanism of action of IAPs in cancer has provided important leads for anticancer drug development.

Structurally, all members of IAPs contain approximately 70 amino acid long Baculovirus IAP Repeats (BIR) domains at the $\mathrm{N}$-terminus, which are essential but not sufficient for their anti-apoptotic activity [15]. Although the number of BIR domains varies among IAP members, each BIR domain is made up of cysteine and histidine residues in a well-defined pattern (Cx2Cx6Wx3Dx5Hx6C), which represents a novel zinc-binding fold. In addition to BIR domain, several viral, mammalian and insect IAPs require a ring finger domain (RING) near the $\mathrm{C}$-terminus for suppression of apoptosis $[9,16]$. However, C-terminal RING is not indispensable for suppression of apoptosis by human c-IAP1, c-IAP2 and XIAP $[17,18]$. Human cIAP-1 and cIAP-2 also contain a Caspase Recruitment Domain (CARD), significance of which is not clearly understood during apoptosis suppression. IAPs also possess additional domains; ubiquitin-associated (UBA) domain (in c-IAP1, c-IAP2, XIAP and hILP2) and ubiquitin-conjugating (UBC) domain (in BRUCE/APOLLON), these domains assist in inducing ubiquitination and proteasome degradation of specific caspases and suppression of apoptosis $[6,19,20]$. Of all the IAPs known so far, Survivin is the smallest IAP protein with a single $\mathrm{N}$-terminus BIR domain and C-terminus Coiled Coil (CC) domain.
As compared to other IAPs, Survivin exhibits most restricted expression in adult tissues and has crucial role in regulating both cell division and apoptosis. It is highly expressed in most human cancers but not in normal, terminally differentiated adult tissues, thus making Survivin an exciting new tumour marker [5].

\section{Molecular organization and structure of Survivin}

Survivin is encoded by BIRC5 gene and consists of 4 exons and 3 introns covering 14,796 nucleotides on chromosome 17q25 forming transcripts with varied functional domains. The BIRC5 gene encodes wild type Survivin (WT, four exons; 142 amino acid) and five known additional splice variants i.e.; $\Delta \mathrm{Ex} 3$ (Survivin with deletion of exon 3; 137 amino acid), 2B (Survivin with an additional exon; 165 amino acids), 3B (five exons; 120 amino acid), $2 \alpha$ ( 2 exons; 74 amino acids), $3 \alpha$ (two exons;78 amino acids) [21-23]. All Survivin isoforms share complete sequence identity in the $\mathrm{N}$-terminus region, including some or the entire BIR domain, but they differ in the carboxyl end [24]. Figure 1 illustrates the various splice variants of Survivin and the amino acid alterations present in each splice variant. Survivin isoforms also have different expression patterns and cellular localization as compared to wild type form, Survivin$\triangle \mathrm{Ex} 3$ is found predominantly in the nucleus where as Survivin- 2B is found in the cytoplasm. Alternative splicing of Survivin has been shown to have correlation with disease activity in various patient studies. Survivin WT, $2 \mathrm{~B}$ and $\Delta \mathrm{Ex} 3$ variants have been extensively investigated for clinical and prognostic association in cancer. Presence of $\Delta \mathrm{Ex} 3$ variant has been associated with unfavourable clinical outcome and prognosis [25]. Conflicting data exists for clinical and pathological correlation of variant $2 \mathrm{~B}$ in cancer; certain studies demonstrate association of $2 \mathrm{~B}$ variant with aggravated disease and poor survival [26] while some studies indicate that presence of $2 \mathrm{~B}$ variant is associated with less severe disease [27]. Overall, there is a consensus that $\triangle \mathrm{Ex} 3$ is anti-apoptotic and $2 \mathrm{~B}$ is pro-apoptotic and that these variants may perform contrasting functions in tumor progression and response to therapy [28]. Presence of Survivin isoforms has also been shown to influence angiogenesis. In a study by Doucette $\mathrm{T}$ et al., presence of Survivin splice variant 2 was associated with poorer survival and promoted malignant progression, angiogenesis, and shorter tumor-free survival in mouse model of glioma [29].

It still remains unclear whether alternative splicing of Survivin is an adaptation used by cancer cells to support their proliferation and avoid detection by immune surveillance Association of splice variants with distinct pathological and survival outcomes indicate possible role of these variants in disease progression. However, relative 


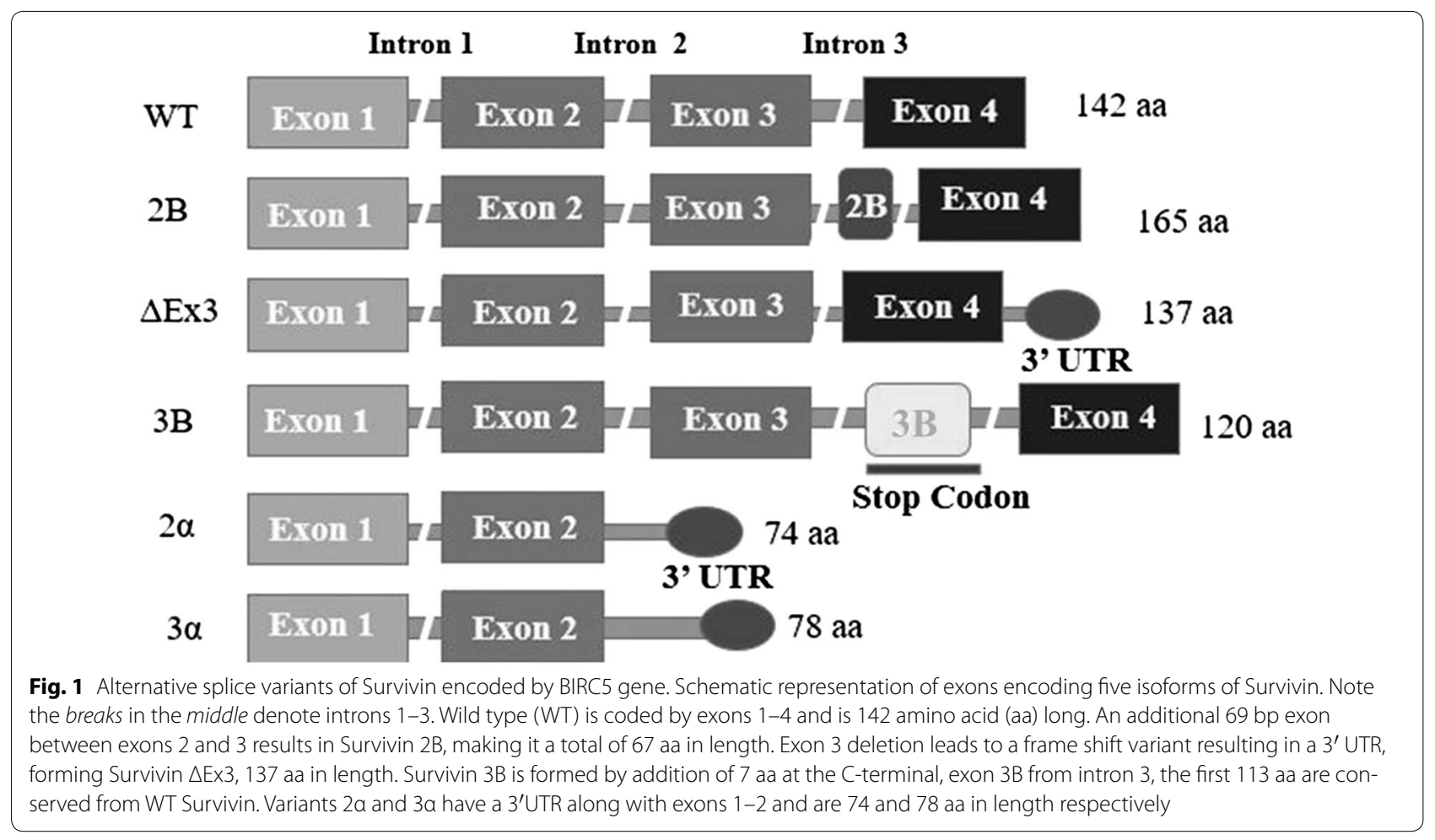

contribution of different splice variants of Survivin with tumorigenesis, immune evasion and response to therapy is not completely understood and warrants further investigation.

\section{Cellular localization of Survivin}

Survivin is predominantly present in the cytosol of tumour cells. However, a smaller nuclear fraction of Survivin localizing to kinetochores of metaphase chromosomes has also been reported in tumour and proliferating cells, indicating that these different subcellular pools of Survivin may have different functions [30, 31]. Cytosolic Survivin is believed to function as apoptotic suppressor while nuclear Survivin is postulated to regulate cell division. However, the pathological significance of nuclear Survivin as a favourable prognostic marker for tumour cells is still debatable. There is equivocal data from patient studies to indicate nuclear/cytosolic Survivin expression as an unfavourable or favourable prognostic marker in cancer [31]. Apart from cytosolic and nuclear pool, Survivin has also been detected in mitochondrion [32] and shown to be released into cytosol in response to cellular stress stimuli and suppress caspase activation [32]. Extracellular pool of Survivin has also been shown to exist as exosomes in form of 40-100 nm membrane vesicles secreted from tumour cells and taken up by surrounding cells [33]. In fact, many IAPs such as
cIAP1, cIAP2 and XIAP including Survivin have been shown to exist as tumour exosomes in cancer cell lines [34]. Exosomes containing Survivin have been shown to re-enter cells and promote tumour growth. Khan et al. have demonstrated that extracellular pool of Survivin has the ability to cause neighbouring cancer cells to increase resistance to therapy, rapidly proliferate, and acquire an increased potential to become invasive in vitro $[35,36]$. Increased levels of plasma derived exosomal Survivin from prostate cancer patients has been shown to correlate with disease severity [37]. Thus, both intracellular and extracellular release of Survivin in cancers may be responsible for aggravated disease.

\section{Multiple roles of Survivin}

Survivin and cell proliferation

Regulation of cell division is recognized as prominent function of Survivin. Normal cells show cell cycle dependent synthesis, expression and degradation of Survivin. Survivin forms an integral component of chromosomal passenger complex (CPC) which ensures proper segregation of chromosomes and cytokinesis during cell division [38]. Various checkpoints ensure nuclear division, attachment to mitotic spindle and cytokinesis. CPC is a hetero-tetrameric complex which localizes to different sites at different times during mitosis, this serves to regulate key events in cell division such as 
chromosome-microtubule attachment, proper spindle assembly and occurrence of cytokinesis. Aurora B kinase is the enzymatic component of $\mathrm{CPC}$ whereas as the other three components; inner centromere protein (INCENP), Survivin and Borealin (also known as Dasra) have regulatory and targeting functions. Alteration in any of the four components can lead to a defect in chromosomal segregation and/or cytokinesis and cause genomic instability [39-42]. Analysis of individual contributions of these proteins to formation of CPC suggests that the enzymatic component Aurora B kinase is directed to mitotic cell by the other three proteins of CPC i.e. INCENP, Survivin and Borealin/Dasra. INCENP acts as a scaffold protein and stabilizes the complex, Borealin acts to promote binding of Survivin to INCENP and Survivin acts as a determining factor in centromere localization of CPC $[43,44]$. Although Survivin acts as a key protein in mediating $\mathrm{CPC}$ targeting, other protein components of $\mathrm{CPC}$ act to promote a stable structure. Furthermore, a distinct pool of subcellular Survivin is associated with polymerized tubulin and regulates microtubule formation during cell division.

\section{Survivin as an inhibitor of apoptosis}

Overexpression of Survivin inhibits both intrinsic and extrinsic pathways of apoptosis [5, 45-48]. Depletion of Survivin in human cells induces defects in apoptosis and multiple defects in cell division [38, 49]. Although the mechanism of inhibition of apoptosis by Survivin is still unknown, both direct and indirect binding of Survivin to initiator or effector caspases is supposed to contribute to inhibition of apoptosis by Survivin [50]. Direct binding of Survivin to effector caspase-3 has been speculated, however, unlike other IAPs, Survivin does not possess the structural moiety responsible for docking of caspase-3 to the BIR domain [51]. Some studies suggest that Survivin binds directly to caspase- 9 and inhibits its activity [52]. Another mechanism proposed for Survivin mediated inhibition of caspase- 9 is binding of hepatitis B X-interaction protein (HBXIP) to procaspase-9. It is also speculated that X-linked IAP (XIAP) which also contains BIR domain leads to an inhibition of caspase- 9 along with Survivin [53, 54]. In yet another mechanism, Survivin inhibits intrinsic (mitochondrial) pathway of apoptosis by binding to pro-apoptotic proteins called Secondary Mitochondria-derived Activator of Caspase (SMAC/ DIABLO). SMAC/DIABLO are released during intrinsic pathway from mitochondria and activate caspase- 9 to induce apoptosis. Survivin binds to SMAC/DIABLO and prevents caspase activation [52]. Song et al. have demonstrated that Survivin physically associates with SMAC/ DIABLO and blocking this interaction induced apoptosis in taxol treated HeLa cells [55].
Taken together, there is substantial evidence to support the dual function of Survivin i.e. as a regulator of cell division and inhibitor of apoptosis (Fig. 2). Wheatley SP reported that the $\mathrm{C}$-terminus of Survivin is required for cell division and the $\mathrm{N}$ - terminus is dispensable for apoptosis [56]. Though, thought as two separate functions, it may be possible that Survivin expression acts as a vital checkpoint for induction of programmed cell death in those cells undergoing aberrant cell division. More studies will be required to confirm whether Survivin exclusively acts as a regulator of cytokinesis or cell death in normal cells and whether either of these functions becomes predominant during tumor progression.

\section{Role of Survivin in supporting angiogenesis, metastasis and chemo-resistance of tumor cells}

One of the pathways responsible for Survivin mediated tumor progression is promotion of angiogenesis in cancer cells. Survivin upregulates VEGF expression and promotes endothelial cell (ECs) proliferation by mechanisms which are still not clear [57]. Existence of a positive feedback loop connecting Survivin expression in tumor cells to PI3K/Akt enhanced $\beta$-catenin-Tcf/Lef-dependent transcription inducing secretion of VEGF and angiogenesis has been suggested [57]. Knockdown of Survivin in glioma has been shown to inhibit angiogenesis [58]. Small interfering RNA (siRNA) mediated silencing of Survivin sensitized human breast cancer cells to apoptosis and inhibited tumour formation and angiogenesis in breast or cervical cancer xenograft model in vivo [59]. Survivin induced VEGF expression also contributes to chemo-resistance by stimulating organization of tubulin into distinct fibres [60]. Survivin is particularly upregulated on tumor vascular ECs as compared to normal tissues, thus conferring drug resistance on tumor vascular ECs [61]. Therefore, targeting Survivin in tumor will promote not only tumor cell death but also sensitize cells of tumor vascular network to chemotherapeutic drugs.

Survivin may also cooperate with other IAP members to promote metastasis. Survivin overexpression enhanced migration of human melanocytes and melanoma cells on fibronectin whereas Survivin knockdown under sub-apoptotic conditions blocked their migration and invasion [62]. Inter-molecular interaction between XIAP and Survivin promoted tumor cell invasion in vitro and metastatic dissemination in vivo in murine model of breast cancer and rat insulinoma. This pathway operated independent of the role of IAPs in cell survival. Signal transduction through this pathway resulted in NF- $\mathrm{KB}$ activation, transcriptional upregulation of fibronectin, autocrine/paracrine signalling by $\beta 1$ integrins, and constitutive phosphorylation, i.e. activation of cell motility kinases i.e.; FAK and Src. implicating direct involvement 


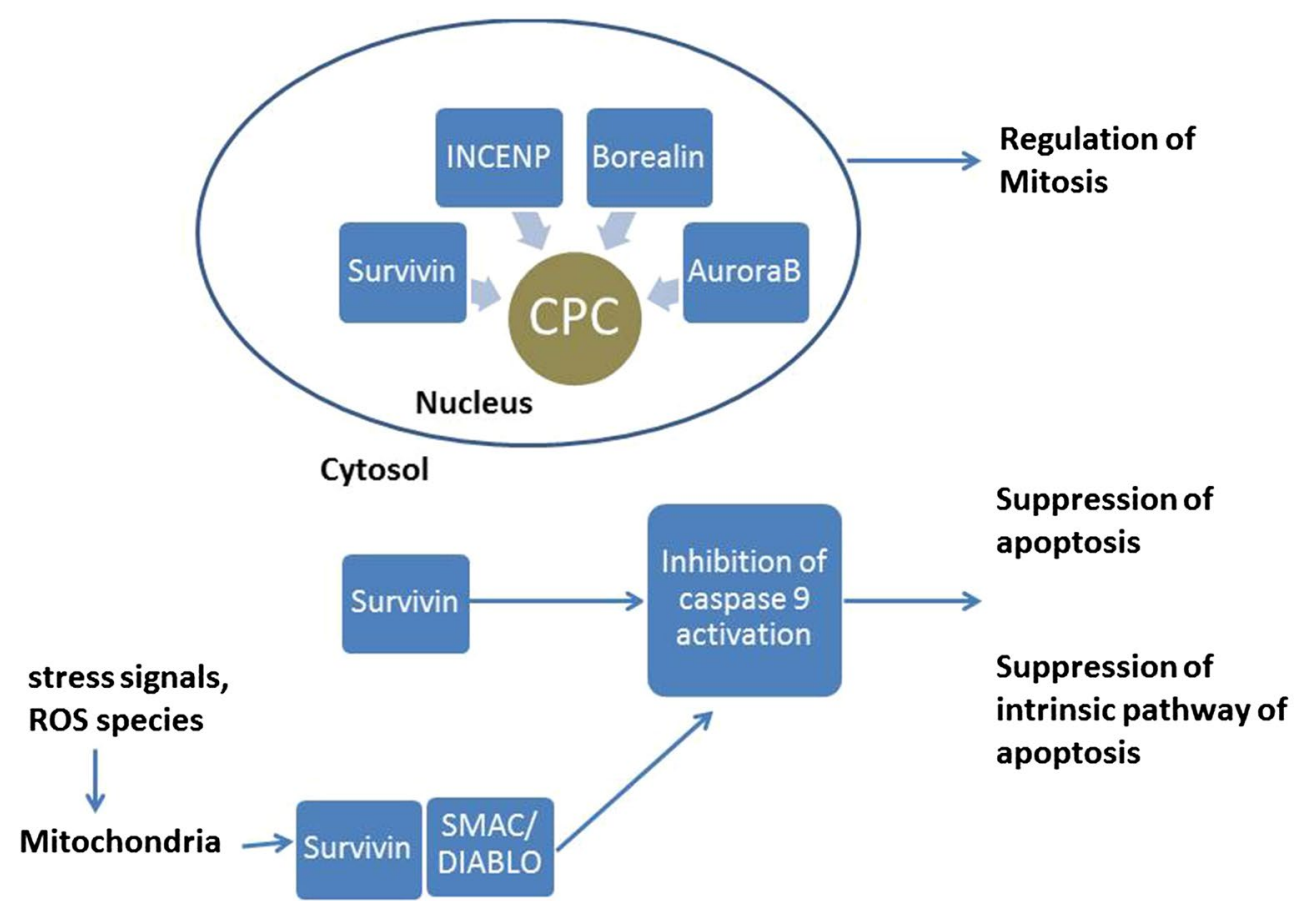

Fig. 2 Unique role of Survivin in both apoptosis and cell division. Survivin expression in cytosol or mitochondrion can suppress both extrinsic and intrinsic pathways of apoptosis. Survivin expression in nucleus plays an important role in regulation of cell division by acting as an important component of chromosome passenger complex (CPC)

of IAPs in promoting metastasis. Most significantly, signal transduction via this pathway did not induce the traditional epithelial-mesenchymal transition (EMT) but rather induced an adhesion gene signature and many fold increase in expression of fibronectin gene in tumor cells [63]. Survivin has also been shown to enhance melanoma cell metastasis through integrin upregulation [64]. Survivin promoted breast cancer lymphatic metastasis through cooperation with vascular endothelial growth factor-C (VEGF-C) [65]. Many patient studies have also indicated that overexpression of Survivin correlates with increased tumour invasion and metastasis $[66,67]$, thereby implicating a wider role for Survivin beyond regulating apoptosis and cell division of cancer cells.

\section{Survivin and cancer stem cells}

Existence of cancer stem cells has been proposed as a primary reason for genesis of cancer and disease relapse. It is hypothesized that tumours are maintained by a subset of tumour stem cells that possess the self-renewal capacity similar to stem cells. Role of Survivin has been shown in regulation of adult stem cell physiology such as in haematopoietic stem cells, neuronal stem cells or intestinal stem cells [68-70]. Survivin is also important for embryonic stem cell and totipotent stem cell function [71]. Since normal stem cells and cancer stem cells share common features, it is plausible to assume that like normal stem cells, Survivin expression on cancer stem cells may also be involved in regulating cancer stem cell behaviour.

An investigation of co-expression of Survivin and stem cell specific proteins in oesophageal squamous cell carcinoma (ESCC) patients revealed that patients exhibiting high expression of both a stem cell specific protein Oct- 4 and Survivin showed worst prognosis. Survivin expression correlated with Oct-4 expression in ESCC cells suggesting a regulation/interaction between Survivin and Oct-4 [72]. Molecular mechanisms underlying the interaction/regulation between Survivin and stem cell specific proteins are still not properly understood. Role of Survivin is also implicated in specifically regulating genes involved in leukemia cancer stem cell (LCSC) fate and not normal hematopoietic stem cell (HSC). This difference in Survivin signalling in LCSC vs HSC opens new avenues for specific therapeutic targeting and elimination of cancer stem cells [73].

\section{Survivin as therapeutic target in cancer}

Survivin commands a central position among IAPs as being both a regulator of cell division and apoptosis. However, normal differentiated cells have very low or no expression of Survivin. Does low or no expression of 
Survivin on normal cells have any correlation with cellular functions or less cell division/apoptosis in normal cells? Survivin knock-out mice exhibit embryonic lethality [74], loss of self-renewing bone marrow progenitor cells and bone marrow ablation [75]. Conditional deletion of Survivin in thymus leads to a developmental block in thymocytes at double negative stage and presence of immature T cells in periphery [76]. Survivin also emerges as a key regulator of clonal expansion of Teff cells [77], proliferation of early $\mathrm{B}$ cell progenitors and activated mature B cells [78], erythroid [79] and megakaryocyte differentiation [80]. Survivin appears to be an intriguing protein regulating functions of various immune cells, hence therapeutic approaches aimed at targeting Survivin need to be carefully evaluated.

\section{Therapeutic approaches targeting Survivin}

Due to important role of Survivin in tumor cell division, apoptosis, chemo resistance and cancer stem cell survival; therapeutic blockade of Survivin in tumor cells may possibly yield cumulative benefits. Various strategies have been envisaged to block the expression or function of Survivin in tumour cells (i) immunotherapeutic approaches to induce immune response against Survivin, (ii) small molecule inhibitors/antagonists to block function of Survivin, (iii) nucleic acid based approaches which interfere with Survivin gene expression or (iv) gene ablation of Survivin to regulate cell cycle and apoptosis.

\section{Survivin based Immunotherapeutic approaches}

Manipulation of host immune system to produce an antitumour response is known as immunotherapy. This concept was first pioneered by William Coley (1891) who used extracts of S. pyogenes and heat-killed Bacillus prodigious (now reclassified as Serratia marcecsens) bacteria to treat sarcomas [81]. Coley's experiments established that immune stimulatory components present in "Coley's toxins" boosted anti-tumor immune response and induced disease remission in cancer. Coley's experimental results were widely criticized and concept of immunotherapy was totally dismissed as an effective strategy to control cancer. Alternative treatment modalities in cancer like chemotherapy and radiotherapy which had been well developed by that time presented with drawbacks of inducing disease resurgence and toxicity. Simultaneously, with better understanding of principles of immunology, it was apparent that immune system had a crucial role in controlling certain types of cancer. As various principles of immunology were being unravelled, it became clear that immunotherapy is a better therapeutic option as compared to chemotherapy or radiotherapy because it is specific for tumor cells and is devoid of side effects.
Immunotherapy eliminates tumor cells by initiating/ boosting anti-tumor immune response or reversing inhibitory immune signalling. Active immunotherapy involves development of a targeted anti-tumor immune response in the host using specific cancer antigens or ex vivo expansion of effector cells and infusion back into the patient. Passive immunotherapy covers transfer of preformed molecules such as therapeutic antibodies or antigen specific $T$ cells which can eliminate or suppress tumor. A number of monoclonal antibodies against growth factor receptors or antigenic determinants on cancer cells have been successfully translated for therapeutic usage in various cancers. Recent success of antibodies targeting inhibitory immune checkpoints such as CTLA-4 and PD-1 has again shifted the focus on inhibitory molecules in immune cell signalling for a beneficial anti-tumor response [82]. Although, diverse approaches for therapeutic cancer vaccines have shown good immunogenicity in clinical trials yet clinical translation of antigen specific cancer vaccines has not been as successful as passive immunotherapy. The rationale for cancer vaccine is to target a specific tumor antigen as vaccine candidate, induce robust antigen presentation mostly through DCs and induction of cytotoxic T cell (CTL) response. Tumor antigens are processed into peptides, loaded onto MHC molecules and MHC-peptide complex is presented by antigen presenting cells (APCs) to T cells for activation. Induction of effector $\mathrm{T}$ cell response is sequential; antigen specific $\mathrm{T}$ cells are first primed in the secondary lymphoid organs through the interaction with APC. APCs particularly dendritic cells (DC) sample antigens from tumor cells and present antigens to $\mathrm{CD} 4+\mathrm{T}$ cells via the MHC class-II pathway or to CD8+ T-cells via cross presentation or cross priming [83, 84]. This antigen recognition in association with MHC is insufficient to effectively activate T cells; APC provide additional co-signals that regulate the breadth of $\mathrm{T}$ cell activation. These multiple co-signals can be induced by stimulatory (CD80/ CD86:CD28) and inhibitory molecules also known as "Immune checkpoints" [85, 86]. Antigen specific T cells once primed by APCs will scan for cognate MHC-peptide on target tumor cells and execute lysis of target cells. Immunotherapy using specific cancer antigens serves to expand the population of antigen specific $\mathrm{T}$ cells so that immune escape of tumor is prevented (Fig. 3). The vaccine strategies employ either peptides or whole recombinant protein in adjuvant, recombinant viruses encoding the antigen of interest or other recombinant microorganisms, DNA vaccines, cytokine or co-stimulation enhanced vaccines, killed tumor cells, or DCs pulsed with protein-or peptide. Incorporating a strong adjuvant enhances tumor antigen presentation and activation of 


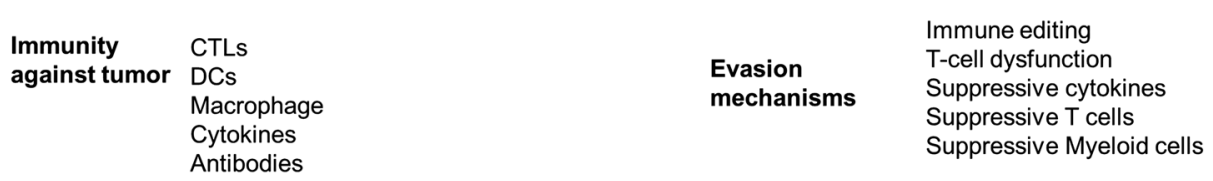

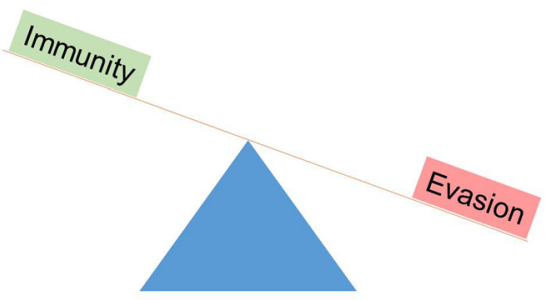

Tumor growth \& Metastasis

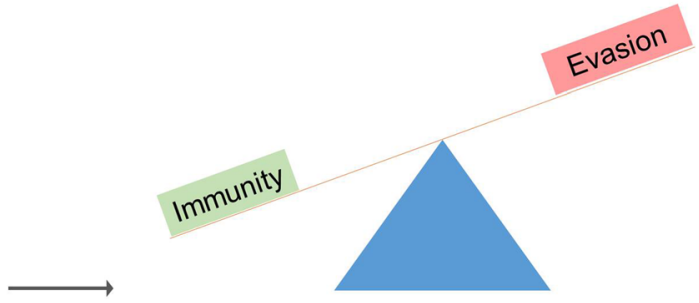

Tumor Immunotherapy

Fig. 3 Immunotherapy in cancer. The self-defence of tumors overweighs the anti-tumor immunity leading to clinical manifestations of cancer. The various immunotherapeutic approaches are adopted to reverse this imbalance

immune effector mechanisms leading to induction of a robust CTL response against tumor cells.

An ideal cancer vaccine should use an antigen which is specific and overexpressed on tumor cells. Survivin has emerged as an ideal antigen for cancer immunotherapy because of tumour specific expression and critical role in regulating cell division and apoptosis of tumour cells. [87-89]. Human transcriptome analysis reveals that Survivin is the fourth most highly expressed transcript in human cancer cells when compared to normal cells [90]. Overexpression of Survivin has been associated with an unfavourable prognosis in colorectal and bladder cancers and neuroblastoma [91, 92], melanoma and nonmelanoma skin cancers [93, 94]. Survivin overexpression also induces an increased chemotherapeutic drug resistance as discussed earlier in the review. Survivin expression confers a survival advantage on tumour cells and can be a universal therapeutic and diagnostic target for all tumours.

Survivin protein has been shown to induce CTL response in vitro when processed and presented by dendritic cells [95] and Survivin derived peptides prime CTLs in vivo in murine model of melanoma [96]. Generation of Survivin specific CTLs that can lyse HLA matched tumour target cells has been demonstrated in cancer patients [97]. Presence of spontaneous CTL response against MHC-I restricted peptide antigens derived from Survivin in patients suffering from melanoma, breast cancer and leukemia strongly indicates that CD8 $\mathrm{T}$ cell restricted epitopes from Survivin are of substantial immunotherapeutic value [98-100]. Induction of effective CTL response was also coupled with homing of Survivin specific CTLs to the site of tumour in situ in melanoma and breast cancer [101] representing a complete synchronization of both local and systemic immune response when using Survivin as a vaccine candidate.

Vaccine approaches such as dendritic cell based (DC) vaccines, DNA vaccines [102], peptide vaccines or VLP based vaccine for Survivin have also been evaluated in preclinical or clinical studies. A DC vaccine trial conducted on non-small cell lung carcinoma (NSCLC) patients who received autologous DCs pulsed with apoptotic bodies of NSCLC showed immunological responses in 4/7 stage III unresectable, and 6/7 stage I/II surgically resected patients [103]. Another vaccine for HLA-A24 positive patients was developed by immunizing HLAA24 restricted Survivin peptide 2B80-88 which induced peptide specific CTL response in urothelial [104], oral [105], colorectal [106] and breast cancer [107] patients with no adverse effects. In another study, same peptide was combined with IFN alpha and immunised in urothelial cancer patients but had no better results as compared to peptide alone [108]. The peptide alone had low immunogenicity and the investigators concluded that combining the peptide with adjuvants such as heat shock proteins, cytokines etc. may boost immune response to the peptide [107]. A combination of HLA restricted Survivin peptides has also been tested in a phase II trial on metastatic melanoma patients who showed prolonged survival post treatment [109]. A multi-epitope vaccine approach using cocktail of five Survivin peptides: EMD640744 and Montanide $\left({ }^{\circledR}\right)$ ISA 51 VG as an adjuvant resulted in anti-Survivin specific $\mathrm{T}$ cell responses in patients with solid cancers [110]. A liposome based 
formulation of Survivin known as DPX-Survivac has also shown to induce Survivin specific immune response in patients with ovarian cancer [111].

Although CTL responses are critical for elimination of tumour cells, role of CD4 T cells and antibodies is also important in modulating anti-tumour immune responses [112]. A number of studies have also shown the important role of CD4 $\mathrm{T}$ cells acting as crucial helper cells to boost CTL function and enhance anti-Survivin immune response [113, 114]. Presence of HLA-class II epitopes to stimulate $\mathrm{T}$ helper cell response has been demonstrated in Survivin peptides $[115,116]$. Sharma et al. have demonstrated an indispensable role of CD4 T cells in sustaining primary and memory anti-tumour immune response in a vaccine formulation containing Survivin evaluated in a transplantable murine model [117]. Importantly, CD4 T cells were crucial in the priming phase of CTLs but not during the effector phase of CTL response. In another important study by Hoffmann et al. recombinant fowl pox virus encoding Survivin derived class I (H1vax1) and class II (H1vax2) derived peptides were designed and evaluated for preclinical efficacy in co-culture experiments using dendritic cells and $\mathrm{T}$ cells isolated from healthy donors. These vaccine constructs showed activation of both antigen specific CD4 and CD8 T cells and cytotoxic activity against Survivin-overexpressing mesothelioma cancer cells [118]. Table 1 summarizes the key conclusions obtained from various Survivin vaccines evaluated in preclinical studies or clinical trials. Preclinical studies with Survivin as vaccine candidate indicate induction of an effective anti-tumor response in animal models of solid or haematological malignancies and support the notion that Survivin is immunogenic in humans. However, the immunogenicity may be low enough to provide protection against tumor cells, therefore antigen delivery and role of adjuvants is important to enhance immunogenicity of this protein Furthermore, both CD4 and CD8 restricted epitopes from Survivin protein are important for induction of effective anti-tumour immune response.

We have also evaluated full length recombinant Survivin protein as a vaccine candidate with Mycobacterium indicus pranii (MIP) as an adjuvant in 4T-1 mouse model of breast cancer. MIP has been shown to act as an excellent immune-modulator in animal models for psoriasis, lung cancer and exercises anti-tumor action against $\mathrm{Sp} 2 / 0$ (myeloma) and EL4 (thymoma) in mice models [119]. Subcutaneous administration of MIP-Survivin generated a tumour protective response and tumour regression in 4T-1 model of breast cancer in a dose dependent manner. MIP as an adjuvant was able to induce a good anti-Survivin antibody titre after immunization with recombinant murine Survivin protein. MIP also has been shown to induce DC activation and enhance antigen presentation [120]. Therefore, we propose that combining full length recombinant Survivin with MIP may generate epitopes which can activate both Survivin specific CD8 and CD4 T cells and induce an effective cell mediated immune response. In addition to mediating a direct cell mediated attack of tumour cells, immunization with recombinant Survivin in mice also elicited production of anti-Survivin antibodies. Pre-existing titre of anti Survivin antibodies in Balb/c mice immunized with recombinant Survivin may also have a role in mediating tumour regression in these mice when transplanted with syngeneic $4 \mathrm{~T}-1$ cells. Our data suggests that a combination of Survivin and MIP may potentiate anti-tumour immune response (Garg et al. Manuscript under preparation).

There is limited data on therapeutic efficacy of antibodies against intracellular antigens; however a study from Guo et al. indicates that intracellular antigens can also be targeted by antibodies, thereby widening the scope of targeting both extracellular and intracellular tumour antigens by antibody immunotherapy [121-123]. While direct evidence for role of anti-Survivin antibodies in inducing therapeutic response is lacking, it is possible that induction of anti-Survivin antibodies after antigen immunization may block the overexpression of Survivin on cancer cells or inhibit Survivin expressed on exosomes. Antibodies against Survivin may also promote NK cell lysis of tumor cells. Spontaneous humoral response against Survivin has also been observed in sera of patients of lung, gastrointestinal and colorectal cancer [124]. Importantly, immune response against Survivin ( $\mathrm{T}$ cell specific or antibodies) was absent in healthy individuals $[97,124]$ implying that immune response elicited after Survivin vaccination is tumour specific and devoid of autoimmune manifestations. Detailed studies will be required to investigate the effect of Survivin immunization on function of immune effector cells as Survivin has important regulatory role in $\mathrm{T}$ cell and $\mathrm{B}$ cell effector responses.

\section{Small molecule inhibitors of Survivin}

Several small molecule inhibitors targeting Survivin have also been evaluated in various in vitro and in vivo studies. Despite the challenges associated with small molecule drug development, these inhibitors are important for understanding Survivin biology and anti-cancer drug development $[134,135]$. YM-155 is a novel small molecule which suppresses transactivation of Survivin through direct binding to its promoter [136]. It selectively suppresses expression of Survivin and induces apoptosis in p53-deficient cancer cells in vitro [136]. YM155 has also shown to be effective in in vivo models of prostate, pancreatic, and lung cancer [136-138]. Terameprocol (EM-1421), a plant derived small molecule is 


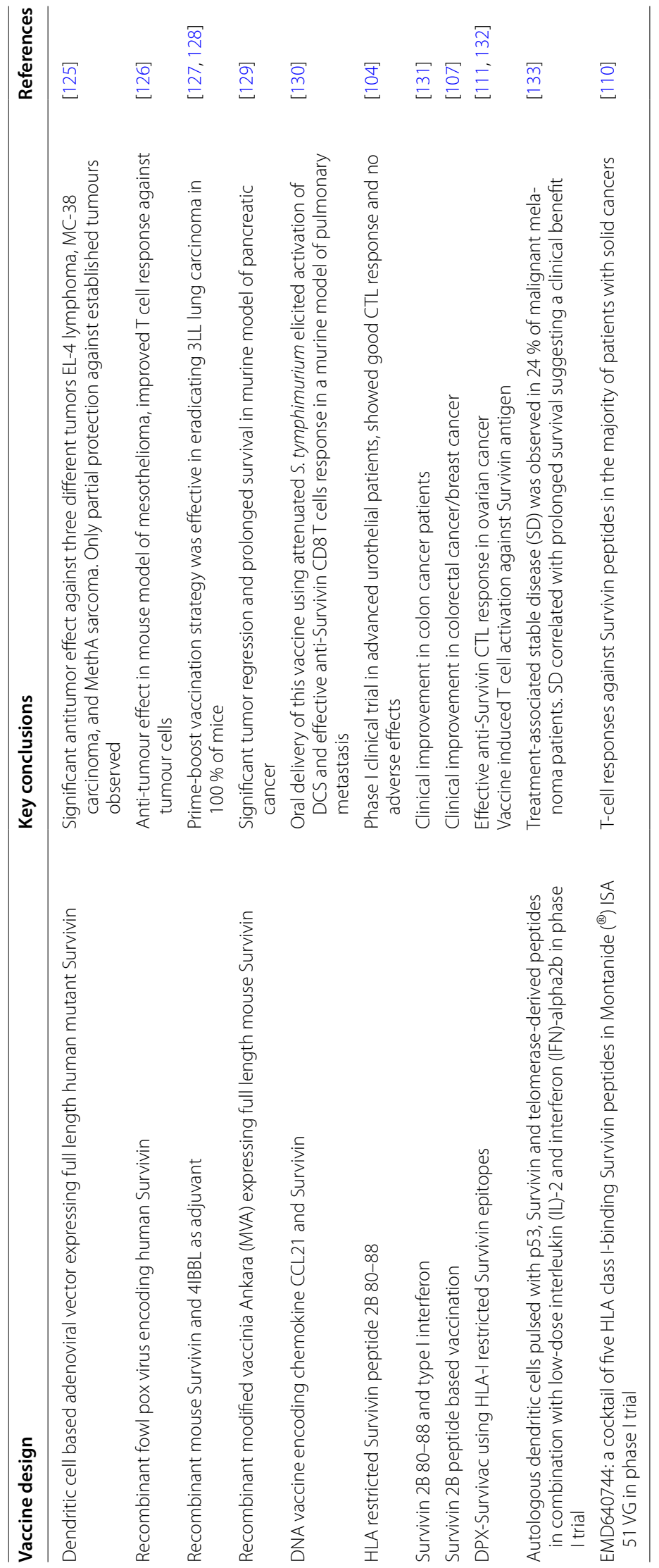


a novel transcription inhibitor which suppresses Survivin gene expression and induces apoptosis of cancer cells [139]. It is in Phase II safety studies as a vaginal ointment in HPV-linked cervical intraepithelial neoplasia [140]. GDP366 is a novel small molecule compound which potently and selectively inhibited the expression of both Survivin and Op18; an onco-protein [141]. Another small molecule Survivin inhibitor FL118 exhibited superior antitumor efficacy in human tumor xenograft models in comparison to standard anti-cancer drugs [142]. Antisense approaches to block Survivin have also been tested. LY2181308, a novel 2'-O-methoxymethyl modified antisense oligonucleotide (2-MOE-ASO), is a specific inhibitor of Survivin mRNA and being investigated for efficacy in clinical trials in various groups of cancer patients [143]. Ribozyme mediated approaches have also been evaluated for inhibition of Survivin expression. Down-regulation of human Survivin gene expression and increased apoptosis was achieved by using two hammerhead ribozymes (RZ1, RZ-2) targeting human Survivin mRNA [144]. Specific Survivin small interfering RNA (siRNA) also inhibited Survivin expression in HL-60 cells and augmented ability of HL-60 cells to overcome drug resistance [145]. siRNA aimed at blocking Survivin-hsp90 connection have also shown anti-cancer effects in androgen independent prostate cancer models [146]. Adenovirus delivered Survivin dominant negative mutants (double point mutant (TC34, 84AA) mediated hepatocellular carcinoma suppression [147]. Another dominant negative mutant (GST-tagged dominant-negative Survivin protein (dNSurR9-C84A) constructed by mutation of Cys84 to Ala in the extreme C-terminal region of the BIR domain of Survivin completely abrogated Survivin's ability to inhibit apoptosis in cancer cell lines [148]. Almost all small molecule inhibitors of Survivin have been designed based on proteinprotein interactions between Survivin and other partner proteins. Since Survivin functions through multiple mechanisms using a variety of partner proteins, blocking one pathway may not entirely lead to reduction of Survivin signalling. Substantial evidence exists in cancer cells for compensatory proliferative mechanisms to override when one signalling pathway is inhibited.

Small molecules are cost effective and have short development time as compared to immunotherapeutic approaches. Therefore, there is enough reasoning to discover and improve existing small molecule inhibitors of Survivin. Immunotherapy approaches, although complex in terms of translational development, are specific and have long lasting effects. However, tumor adaption and immune evasion is one bottleneck to success of immunotherapy strategies. Moreover, either small molecule or immunotherapy targeting Survivin alone has not demonstrated a completely curative response therefore a synergistic combination of small molecules with immunotherapy may be explored to induce and sustain tumor elimination over a course of time.

\section{Conclusions}

Survivin has emerged as a unique and nodal molecule mediating diverse roles in cancer cells. However occurrence of different subcellular pools and splice variants of Survivin complicate the biology of this molecule. Occurrence of particular splice variants in various stages of tumor development needs to be thoroughly investigated for therapeutic translation of Survivin blocking approaches. It is also intriguing to note that differential cellular localization of Survivin has different functional outcomes. While its role in cell division and apoptosis has been substantially investigated there is still paucity of data on contribution of Survivin to immune evasion by tumor cells. Circulating tumor cells also express high levels of Survivin and may also be responsible for immune escape of tumor cells. Chronic inflammation and immune evasion may work synergistically to induce Survivin upregulation on tumor cells. Nonetheless, there has been an increasing interest to develop immunotherapeutic approaches targeting Survivin because of its prominent role in cancer development and ability to induce an effective CTL response. Several studies have shown promising results in preclinical evaluation while some have advanced to stage- I or -II clinical trials. The safety and toxicity profile for Survivin has also shown promising outcome. Figure 4 summarizes conceivable benefits of using Survivin inhibitors or immunotherapeutic approaches using Survivin as an antigen. Given the tremendous heterogeneity in human cancers, translational development for Survivin based vaccines or inhibitors of Survivin may even show better results if used in combination with traditional therapies. Combinatorial therapy using Survivin as vaccine and immune checkpoint blockade (PD-1, CTLA-4 etc.) may also be considered for an efficient anti-tumor immune response. 


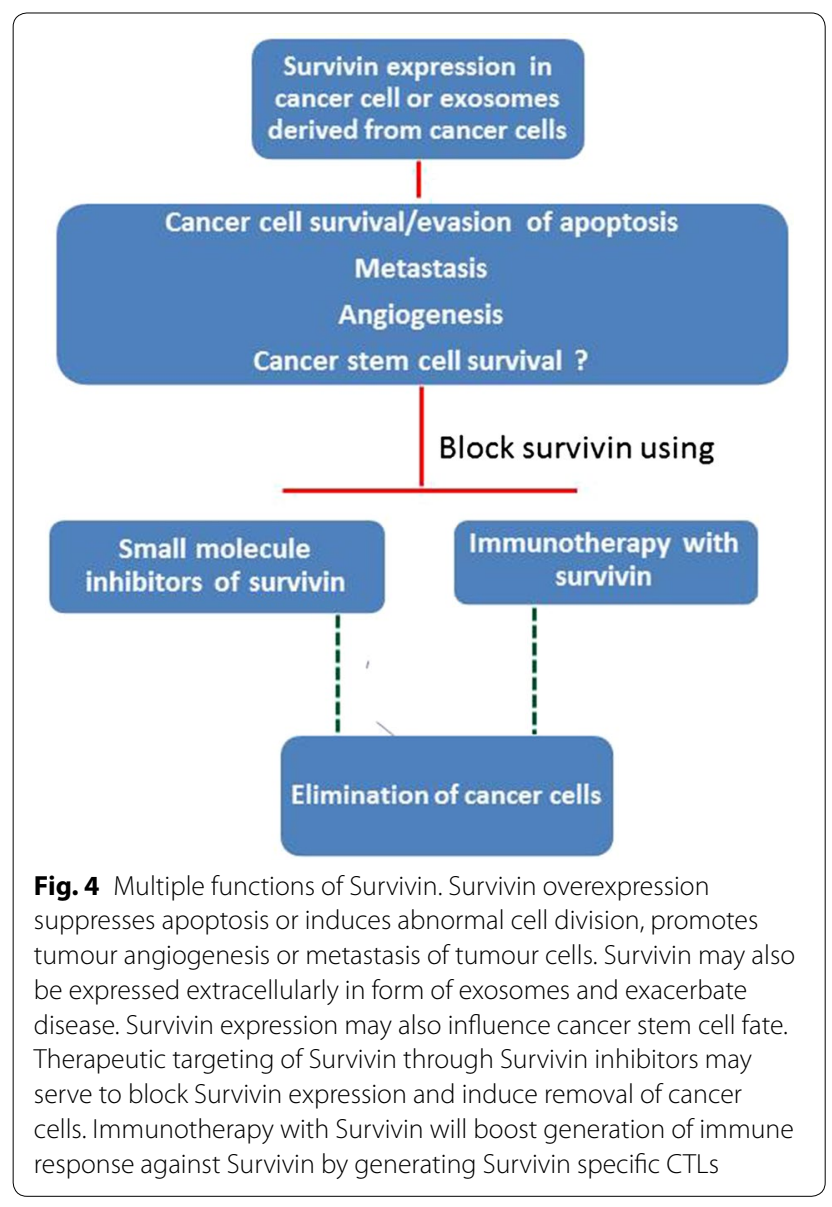

\section{Authors' contributions}

All authors read and approved the final manuscript.

\section{Author details}

1 Amity Institute of Virology and Immunology, Amity University Uttar Pradesh, J-3 Block, Room No: LG21, Sector 125, Noida, Uttar Pradesh 201303, India.

${ }^{2}$ Amity Institute of Biotechnology, Amity University Uttar Pradesh, Sector 125, Noida, India. ${ }^{3}$ Talwar Research Foundation, E-8 Neb Valley, Neb Sarai, New Delhi 110 068, India.

\section{Acknowledgements}

SD acknowledges funding support from Department of Science and technology/SERB, India, Grant sanction number (SR/FT/LS-75/2012). SD also acknowledges infrastructural support from Dr. Ashok K. Chauhan, Founder President, Amity University Uttar Pradesh and Prof. Narayan Rishi, Advisor, Amity Institute of Virology and Immunology, Amity University Uttar Pradesh, Noida, India.

\section{Competing interests}

The authors declare that they have no competing interests.

Received: 17 February 2016 Accepted: 10 June 2016

Published online: 23 June 2016

\section{References}

1. Rothe M, Pan MG, Henzel WJ, Ayres TM, Goeddel DV. The TNFR2-TRAF signaling complex contains two novel proteins related to baculoviral inhibitor of apoptosis proteins. Cell. 1995;83(7):1243-52.
2. Duckett CS, Nava VE, Gedrich RW, Clem RJ, Van Dongen JL, Gilfillan MC, Shiels H, Hardwick JM, Thompson CB. A conserved family of cellular genes related to the baculovirus iap gene and encoding apoptosis inhibitors. EMBO J. 1996;15(11):2685-94.

3. Rajcan-Separovic E, Liston P, Lefebvre C, Korneluk RG. Assignment of human inhibitor of apoptosis protein (IAP) genes xiap, hiap-1, and hiap-2 to chromosomes Xq25 and 11q22-q23 by fluorescence in situ hybridization. Genomics. 1996;37(3):404-6.

4. Liston P, Roy N, Tamai K, Lefebvre C, Baird S, Cherton-Horvat G, Farahani R, McLean M, Ikeda JE, MacKenzie A, et al. Suppression of apoptosis in mammalian cells by NAIP and a related family of IAP genes. Nature. 1996;379(6563):349-53.

5. Ambrosini G, Adida C, Altieri DC. A novel anti-apoptosis gene, Survivin, expressed in cancer and lymphoma. Nat Med. 1997;3(8):917-21.

6. Hauser HP, Bardroff M, Pyrowolakis G, Jentsch S. A giant ubiquitinconjugating enzyme related to IAP apoptosis inhibitors. J Cell Biol. 1998;141(6):1415-22.

7. Salvesen GS, Duckett CS. IAP proteins: blocking the road to death's door. Nat Rev Mol Cell Biol. 2002;3(6):401-10.

8. LaCasse EC, Mahoney DJ, Cheung HH, Plenchette S, Baird S, Korneluk RG. IAP-targeted therapies for cancer. Oncogene. 2008;27(48):6252-75.

9. Clem RJ, Miller LK. Control of programmed cell death by the baculovirus genes p35 and iap. Mol Cell Biol. 1994;14(8):5212-22.

10. Birnbaum MJ, Clem RJ, Miller LK. An apoptosis-inhibiting gene from a nuclear polyhedrosis virus encoding a polypeptide with Cys/His sequence motifs. J Virol. 1994;68(4):2521-8.

11. Kelly R, Lopez-Chavez A, Citrin D, Janik JE, Morris JC. Impacting tumorcell fate by targeting the inhibitor of apoptosis protein Survivin. Mol Cancer. 2011;10:35.

12. Deveraux $\mathrm{QL}$, Reed JC. IAP family proteins-suppressors of apoptosis. Genes Dev. 1999;13(3):239-52.

13. Deveraux QL, Stennicke HR, Salvesen GS, Reed JC. Endogenous inhibitors of caspases. J Clin Immunol. 1999;19(6):388-98.

14. Fukuda S, Pelus LM. Survivin, a cancer target with an emerging role in. Mol Cancer Ther. 2006;5:1087-98.

15. Schimmer AD. Inhibitor of apoptosis proteins: translating basic knowledge into clinical practice. Cancer Res. 2004;64(20):7183-90.

16. Harvey AJ, Soliman H, Kaiser WJ, Miller LK. Anti- and pro-apoptotic activities of baculovirus and Drosophila IAPs in an insect cell line. Cell Death Differ. 1997;4(8):733-44.

17. Roy N, Deveraux QL, Takahashi R, Salvesen GS, Reed JC. The c-IAP-1 and C-IAP-2 proteins are direct inhibitors of specific caspases. EMBO J. 1997;16(23):6914-25.

18. Deveraux QL, Takahashi R, Salvesen GS, Reed JC. X-linked IAP is a direct inhibitor of cell-death proteases. Nature. 1997;388(6639):300-4.

19. Blankenship JW, Varfolomeev E, Goncharov T, Fedorova AV, Kirkpatrick DS, Izrael-Tomasevic A, Phu L, Arnott D, Aghajan M, Zobel K, et al. Ubiquitin binding modulates IAP antagonist-stimulated proteasomal degradation of C-IAP1 and c-IAP2(1). Biochem J. 2009;417(1):149-60.

20. Gyrd-Hansen M, Darding M, Miasari M, Santoro MM, Zender L, Xue W, Tenev T, da Fonseca PC, Zvelebil M, Bujnicki JM, et al. IAPs contain an evolutionarily conserved ubiquitin-binding domain that regulates NF-kappaB as well as cell survival and oncogenesis. Nat Cell Biol. 2008;10(11):1309-17.

21. Mahotka C, Liebmann J, Wenzel M, Suschek C, Schmitt M, Gabbert H. Differential subcellular localization of functionally. Cell Death Differ. 2002;9:1334-42.

22. Caldas H, Honsey LE, Altura RA. Survivin 2alpha: a novel Survivin splice variant expressed in human malignancies. Mol Cancer. 2005;4(1):11.

23. Sampath J, Pelus LM. Alternative splice variants of Survivin as potential targets in cancer. Curr Drug Discov Technol. 2007:4(3):174-91.

24. de Necochea-Campio R, Chen C-S, Mirshahidi S, Howard FD, Wall NR. Clinico-pathologic relevance of Survivin splice variant expression. Cancer Lett. 2013;339:167-74.

25. Necochea-Campion R, Chen CS, Mirshahidi S, Howard FD, Wall NR. Clinico-pathologic relevance of Survivin splice variant expression in cancer. Cancer Lett. 2013:339(2):167-74.

26. Antonacopoulou AG, Floratou K, Bravou V, Kottorou A, Dimitrakopoulos Fl, Marousi S, Stavropoulos M, Koutras AK, Scopa CD, Kalofonos HP. The Survivin -31 snp in human colorectal cancer correlates with Survivin 
splice variant expression and improved overall survival. Anal Cell Pathol (Amst). 2010;33(5):177-89.

27. Suga K, Yamamoto T, Yamada Y, Miyatake S, Nakagawa T, Tanigawa N Correlation between transcriptional expression of Survivin isoforms and clinicopathological findings in human colorectal carcinomas. Oncol Rep. 2005;13(5):891-7.

28. Li F. Role of Survivin and its splice variants in tumorigenesis. Br J Cancer. 2005;92:212-6.

29. Doucette T, Latha K, Yang Y, Fuller GN, Rao A, Rao G. Survivin transcript variant 2 drives angiogenesis and malignant progression in proneural gliomas. Neuro Oncol. 2014;16(9):1220-8.

30. Engels K, Knauer SK, Metzler D, Simf C, Struschka O, Bier C, Mann W, Kovacs AF, Stauber RH. Dynamic intracellular Survivin in oral squamous cell carcinoma: underlying molecular mechanism and potential as an early prognostic marker. J Pathol. 2007;211(5):532-40.

31. Li F, Yang J, Ramnath N, Javle MM, Tan D. Nuclear or cytoplasmic expression of Survivin: what is the significance? Int J Cancer. 2005:114(4):509-12.

32. Dohi T, Beltrami E, Wall NR, Plescia J, Altieri DC. Mitochondrial Survivin inhibits apoptosis and promotes tumorigenesis. J Clin Investig. 2004;114(8):1117-27.

33. Khan $\mathrm{S}$, Bennit HF, Wall NR. The emerging role of exosomes in Survivin secretion. Histol Histopathol. 2015;30(1):43-50.

34. Valenzuela MMA, Ferguson Bennit HR, Gonda A, Diaz Osterman CJ, Hibma A, Khan S, Wall NR. Exosomes secreted from human cancer cell lines contain inhibitors of apoptosis (IAP). Cancer Microenviron. 2015;8(2):65-73.

35. Khan S, Aspe JR, Asumen MG, Almaguel F, Odumosu O, Acevedo-Martinez S, De Leon M, Langridge WH, Wall NR. Extracellular, cell-permeable Survivin inhibits apoptosis while promoting proliferative and metastatic potential. Br J Cancer. 2009;100(7):1073-86.

36. Khan S, Jutzy JM, Aspe JR, McGregor DW, Neidigh JW, Wall NR. Survivin is released from cancer cells via exosomes. Apoptosis Int J Program Cell Death. 2011;16(1):1-12.

37. Khan S, Jutzy JM, Valenzuela MM, Turay D, Aspe JR, Ashok A, Mirshahidi S, Mercola D, Lilly MB, Wall NR. Plasma-derived exosomal Survivin, a plausible biomarker for early detection of prostate cancer. PLoS One. 2012;7(10):e46737.

38. Li F, Ackermann EJ, Bennett CF, Rothermel AL, Plescia J, Tognin S, Villa A, Marchisio PC, Altieri DC. Pleiotropic cell-division defects and apoptosis induced by interference with Survivin function. Nat Cell Biol. 1999:1 (8):461-6.

39. Ruchaud S, Carmena M, Earnshaw WC. The chromosomal passenger complex: one for all and all for one. Cell. 2007;131(2):230-1.

40. Ruchaud S, Carmena M, Earnshaw WC. Chromosomal passengers: conducting cell division. Nat Rev Mol Cell Biol. 2007:8(10):798-812.

41. Roland SH, Mann W, Shirley KK. Nuclear and cytoplasmic Survivin: molecular mechanism, prognostic, and therapeutic potential. Cancer Res. 2007;67:5999-6002

42. Kitagawa M, Lee $\mathrm{SH}$. The chromosomal passenger complex (CPC) as a key orchestrator of orderly mitotic exit and cytokinesis. Front Cell Dev Biol. 2015;3:14.

43. Vader G, Kauw JJ, Medema RH, Lens SM. Survivin mediates targeting of the chromosomal passenger complex to the centromere and midbody. EMBO Rep. 2006:7(1):85-92.

44. Lens SM, Vader G, Medema RH. The case for Survivin as mitotic regulator. Curr Opin Cell Biol. 2006;18(6):616-22.

45. Tamm I, Wang Y, Sausville E, Scudiero DA, Vigna N, OltersdorfT, Reed JC. IAP-family protein Survivin inhibits caspase activity and apoptosis induced by Fas (CD95), Bax, caspases, and anticancer drugs. Cancer Res. 1998;58(23):5315-20.

46. Kobayashi K, Hatano M, Otaki M, Ogasawara T, Tokuhisa T. Expression of a murine homologue of the inhibitor of apoptosis protein is related to cell proliferation. Proc Natl Acad Sci USA. 1999;96(4):1457-62.

47. Mahotka C, Wenzel M, Springer E, Gabbert HE, Gerharz CD. SurvivindeltaEx3 and Survivin-2B: two novel splice variants of the apoptosis inhibitor Survivin with different antiapoptotic properties. Cancer Res. 1999:59(24):6097-102.

48. Altieri DC. The molecular basis and potential role of Survivin in cancer diagnosis and therapy. Trends Mol Med. 2001;7(12):542-7.
49. Adams RR, Carmena M, Earnshaw WC. Chromosomal passengers and the (aurora) ABCs of mitosis. Trends Cell Biol. 2001;11(2):49-54.

50. Cheung CHA, Huang CC, Tsai FY, Lee JY, Cheng SM, Chang YC, Huang YC, Chen SH, Chang JY. Survivin - biology and potential as a therapeutic target in oncology. OncoTargets Ther. 2013;6:1453-62.

51. Eckelman BP, Salvesen GS, Scott FL. Human inhibitor of apoptosis proteins: why XIAP is the black sheep of the family. EMBO Rep. 2006; 7(10):988-94.

52. Johnson ME, Howerth EW. Survivin: a bifunctional inhibitor of apoptosis protein. Vet Pathol. 2004;41 (6):599-607.

53. Mita AC, Mita MM, Nawrocki ST, Giles FJ. Survivin: key regulator of mitosis and apoptosis and novel target for cancer therapeutics. Clin Cancer Res. 2008;14:5000-5.

54. Marusawa $\mathrm{H}$, Matsuzawa S, Welsh $\mathrm{K}$, et al. HBXIP functions as a cofactor of Survivin in apoptosis suppresion. EMBO J. 2003;22:2729-69.

55. Song Z, Yao X, Wu M. Direct interaction between Survivin and Smac/ DIABLO is essential for the anti-apoptotic activity of Survivin during taxol-induced apoptosis. J Biol Chem. 2003;278(25):23130-40.

56. Wheatley SP. The functional repertoire of Survivin's tails. Cell Cycle. 2015;14(2):261-8

57. Fernandez JG, Rodriguez DA, Valenzuela M, Calderon C, Urzua U, Munroe D, Rosas C, Lemus D, Diaz N, Wright MC, et al. Survivin expression promotes VEGF-induced tumor angiogenesis via PI3K/Akt enhanced beta-catenin/Tcf-Lef dependent transcription. Mol Cancer. 2014;13:209.

58. Wang P, Zhen H, Zhang J, Zhang W, Zhang R, Cheng X, Guo G, Mao $X$, Wang J, Zhang $X$. Survivin promotes glioma angiogenesis through vascular endothelial growth factor and basic fibroblast growth factor in vitro and in vivo. Mol Carcinog. 2012;51(7):586-95.

59. Li QX, Zhao J, Liu JY, Jia LT, Huang HY, Xu YM, Zhang Y, Zhang R, Wang $C J$, Yao LB, et al. Survivin stable knockdown by siRNA inhibits tumor cell growth and angiogenesis in breast and cervical cancers. Cancer Biol Ther. 2006;5(7):860-6.

60. Tran J, Master Z, Yu JL, Rak J, Dumont DJ, Kerbel RS. A role for Survivin in chemoresistance of endothelial cells mediated by VEGF. Proc Natl Acad Sci USA. 2002;99(7):4349-54.

61. Virrey JJ, Guan S, Li W, Schonthal AH, Chen TC, Hofman FM. Increased Survivin expression confers chemoresistance to tumor-associated endothelial cells. Am J Pathol. 2008;173(2):575-85.

62. McKenzie JA, Grossman D. Role of the apoptotic and mitotic regulator Survivin in melanoma. Anticancer Res. 2012;32(2):397-404.

63. Mehrotra S, Languino LR, Raskett CM, Mercurio AM, Dohi T, Altieri DC. IAP regulation of metastasis. Cancer Cell. 2010;17(1):53-64.

64. McKenzie JA, LiuT, Jung JY, Jones BB, Ekiz HA, Welm AL, Grossman D. Survivin promotion of melanoma metastasis requires upregulation of alpha5 integrin. Carcinogenesis. 2013;34(9):2137-44.

65. Cai X, Ma S, Gu M, Zu C, Qu W, Zheng X. Survivin regulates the expression of VEGF-C in lymphatic metastasis of breast cancer. Diagn Pathol. 2012;7:52.

66. Chu XY, Chen LB, Wang JH, Su QS, Yang JR, Lin Y, Xue L, Liu XB, Mo XB. Overexpression of Survivin is correlated with increased invasion and metastasis of colorectal cancer. J Surg Oncol. 2012;105(6):520-8.

67. Zhang M, Coen JJ, Suzuki Y, Siedow MR, Niemierko A, Khor LY, Pollack A, Zhang Y, Zietman AL, Shipley WU, et al. Survivin is a potential mediator of prostate cancer metastasis. Int J Radiat Oncol Biol Phys. 2010:78(4):1095-103.

68. Fukuda S, Mantel CR, Pelus LM. Survivin regulates hematopoietic progenitor cell proliferation through p21WAF1/Cip1-dependent and -independent pathways. Blood. 2004;103(1):120-7.

69. Feng R, Zhou S, Liu Y, Song D, Luan Z, Dai X, Li Y, Tang N, Wen J, Li L. Sox 2 protects neural stem cells from apoptosis via up-regulating Survivin expression. Biochem J. 2013;450(3):459-68.

70. Nakaya T, Ogawa S, Manabe I, Tanaka M, Sanada M, Sato T, Taketo MM, Nakao K, Clevers H, Fukayama M, et al. KLF5 regulates the integrity and oncogenicity of intestinal stem cells. Cancer Res. 2014;74(10):2882-91.

71. Mull AN, Klar A, Navara CS. Differential localization and high expression of SURVIVIN splice variants in human embryonic stem cells but not in differentiated cells implicate a role for SURVIVIN in pluripotency. Stem cell Res. 2014;12(2):539-49.

72. Li C, Yan Y, Ji W, Bao L, Qian H, Chen L, Wu M, Chen H, Li Z, Su C. OCT4 positively regulates Survivin expression to promote cancer cell 
proliferation and leads to poor prognosis in esophageal squamous cell carcinoma. PLoS One. 2012;7(11):e49693.

73. Fukuda S, Abe M, Onishi C, Taketani T, Purevsuren J, Yamaguchi S, Conway EM, Pelus LM. Survivin selectively modulates genes deregulated in human leukemia stem cells. J Oncol. 2011;2011:946936.

74. Uren AG, Wong L, Pakusch M, Fowler KJ, Burrows FJ, Vaux DL, Choo $\mathrm{KH}$. Survivin and the inner centromere protein INCENP show similar cell-cycle localization and gene knockout phenotype. Curr Biol. 2000;10(21):1319-28.

75. Fukuda S, Hoggatt J, Singh P, Abe M, Speth JM, Hu P, Conway EM, Nucifora G, Yamaguchi S, Pelus LM. Survivin modulates genes with divergent molecular functions and regulates proliferation of hematopoietic stem cells through Evi-1. Leukemia. 2015;29(2):433-40.

76. Okada H, Bakal C, Shahinian A, Elia A, Wakeham A, Suh WK, Duncan GS, Ciofani M, Rottapel R, Zuniga-Pflucker JC, et al. Survivin loss in thymocytes triggers p53-mediated growth arrest and p53-independent cell death. J Exp Med. 2004;199(3):399-410.

77. Song J, So T, Cheng M, Tang X, Croft M. Sustained Survivin expression from OX40 costimulatory signals drives T cell clonal expansion. Immunity. 2005;22(5):621-31.

78. Miletic AV, Jellusova J, Cato MH, Lee CR, Baracho GV, Conway EM, Rickert RC. Essential role for Survivin in the proliferative expansion of progenitor and mature B cells. J Immunol. 2016;196(5):2195-204.

79. Leung CG, Xu Y, Mularski B, Liu H, Gurbuxani S, Crispino JD. Requirements for Survivin in terminal differentiation of erythroid cells and maintenance of hematopoietic stem and progenitor cells. J Exp Med. 2007;204(7):1603-11.

80. Gurbuxani S, Xu Y, Keerthivasan G, Wickrema A, Crispino JD. Differential requirements for Survivin in hematopoietic cell development. Proc Natl Acad Sci USA. 2005;102(32):11480-5.

81. McCarthy EF. The toxins of William B. Coley and the treatment of bone and soft-tissue sarcomas. lowa Orthop J. 2006;26:154-8.

82. Pardoll DM. The blockade of immune checkpoints in cancer immunotherapy. Nat Rev Cancer. 2012;12(4):252-64.

83. Diamond MS, Kinder M, Matsushita H, Mashayekhi M, Dunn GP, Archambault JM, Lee H, Arthur CD, White JM, Kalinke U, et al. Type I interferon is selectively required by dendritic cells for immune rejection of tumors. J Exp Med. 2011;208(10):1989-2003.

84. Steinman RM, Banchereau J. Taking dendritic cells into medicine. Nature. 2007:449(7161):419-26.

85. Topalian SL, Drake CG, Pardoll DM. Immune checkpoint blockade: a common denominator approach to cancer therapy. Cancer Cell. 2015;27(4):450-61.

86. Pardoll D. Cancer and the immune system: basic Concepts and targets for intervention. Semin Oncol. 2015;42(4):523-38.

87. Andersen MH, Svane IM, Becker JC, Straten PT. The universal character of the tumor-associated antigen Survivin. Clin Cancer Res. 2007:13(20):5991-4.

88. Ambrosini G, Adida C, Sirugo G, Altieri DC. Induction of apoptosis and inhibition of cell proliferation by Survivin gene targeting. J Biol Chem. 1998;273(18):11177-82.

89. Asanuma K, Moriai R, Yajima T, Yagihashi A, Yamada M, Kobayashi D, Watanabe N. Survivin as a radioresistance factor in pancreatic cancer. Jpn J Cancer Res. 2000;91 (11):1204-9.

90. Velculescu VE, Madden SL, Zhang L, Lash AE, Yu J, Rago C, Lal A, Wang CJ, Beaudry GA, Ciriello KM, et al. Analysis of human transcriptomes. Nat Genet. 1999;23(4):387-8.

91. Kawasaki H, Altieri DC, Lu CD, Toyoda M, Tenjo T, Tanigawa N. Inhibition of apoptosis by Survivin predicts shorter survival rates in colorectal cancer. Cancer Res. 1998;58(22):5071-4.

92. Swana HS, Grossman D, Anthony JN, Weiss RM, Altieri DC. Tumor content of the antiapoptosis molecule Survivin and recurrence of bladder cancer. New Engl J Med. 1999;341 (6):452-3.

93. Grossman D, MCNiff JM, Li F, Altieri DC. Expression and targeting of the apoptosis inhibitor, Survivin, in human melanoma. J Invest Dermatol. 1999:113(6):1076-81.

94. Grossman D, McNiff JM, Li F, Altieri DC. Expression of the apoptosis inhibitor, Survivin, in nonmelanoma skin cancer and gene targeting in a keratinocyte cell line. Lab Invest. 1999;79(9):1121-6.

95. Schmitz M, Diestelkoetter P, Weigle B, Schmachtenberg F, Stevanovic S, Ockert D, Rammensee HG, Rieber EP. Generation of Survivin-specific
CD8+T effector cells by dendritic cells pulsed with protein or selected peptides. Cancer Res. 2000;60(17):4845-9.

96. Hofmann UB, Voigt H, Andersen MH, Straten PT, Becker JC, Eggert AO, Identification and characterization of Survivin-derived $\mathrm{H}-2 \mathrm{~Kb}$-restricted CTL epitopes. Eur J Immunol. 2009;39(5):1419-24.

97. Andersen MH, Pedersen LO, Becker JC, Straten PT. Identification of a cytotoxic T lymphocyte response to the apoptosis inhibitor protein Survivin in cancer patients. Cancer Res. 2001;61(3):869-72.

98. Siegel S, Steinmann J, Schmitz N, Stuhlmann R, Dreger P, Zeis M. Identification of a Survivin-derived peptide that induces HLAA*0201-restricted antileukemia cytotoxic T lymphocytes. Leukemia. 2004;18(12):2046-7.

99. Reker S, Meier A, Holten-Andersen L, Svane IM, Becker JC, thor Straten $\mathrm{P}$, Andersen MH. Identification of novel Survivin-derived CTL epitopes. Cancer Biol Ther. 2004;3(2):173-9.

100. Reker S, Becker JC, Svane IM, Ralfkiaer E, Straten PT, Andersen MH. HLAB35-restricted immune responses against Survivin in cancer patients. Int J Cancer. 2004;108(6):937-41.

101. Andersen MH, Pedersen LO, Capeller B, Brocker EB, Becker JC, thor Straten P. Spontaneous cytotoxic T-cell responses against Survivinderived MHC class I-restricted T-cell epitopes in situ as well as ex vivo in cancer patients. Cancer Res. 2001:61(16):5964-8.

102. Zhu K, Qin H, Cha SC, Neelapu SS, Overwijk W, Lizee GA, Abbruzzese JL, Hwu P, Radvanyi L, Kwak LW, et al. Survivin DNA vaccine generated specific antitumor effects in pancreatic carcinoma and lymphoma mouse models. Vaccine. 2007;25(46):7955-61.

103. Hirschowitz EA, Foody T, Hidalgo GE, Yannelli JR. Immunization of NSCLC patients with antigen-pulsed immature autologous dendritic cells. Lung Cancer. 2007;57(3):365-72.

104. Honma I, Kitamura H, Torigoe T, Takahashi A, Tanaka T, Sato E, Hirohashi Y, Masumori N, Tsukamoto T, Sato N. Phase I clinical study of anti-apoptosis protein Survivin-derived peptide vaccination for patients with advanced or recurrent urothelial cancer. Cancer Immunol Immunother. 2009;58(11):1801-7.

105. Miyazaki A, Kobayashi J, Torigoe T, Hirohashi Y, Yamamoto T, Yamaguchi A, Asanuma H, Takahashi A, Michifuri Y, Nakamori K, et al. Phase I clinical trial of Survivin-derived peptide vaccine therapy for patients with advanced or recurrent oral cancer. Cancer Sci. 2011;102(2):324-9.

106. Tsuruma T, Hata F, Torigoe T, Furuhata T, Idenoue S, Kurotaki T, Yamamoto M, Yagihashi A, Ohmura T, Yamaguchi K, et al. Phase I clinical study of anti-apoptosis protein, Survivin-derived peptide vaccine therapy for patients with advanced or recurrent colorectal cancer. J Transl Med. 2004;2(1):19.

107. Tsuruma T, Iwayama Y, Ohmura T, Katsuramaki T, Hata F, Furuhata T, Yamaguchi K, Kimura Y, Torigoe T, Toyota N, et al. Clinical and immunological evaluation of anti-apoptosis protein, Survivin-derived peptide vaccine in phase I clinical study for patients with advanced or recurrent breast cancer. J Transl Med. 2008:6:24.

108. Tanaka T, Kitamura H, Inoue R, Nishida S, Takahashi-Takaya A, Kawami S, Torigoe T, Hirohashi Y, Tsukamoto T, Sato N, et al. Potential survival benefit of anti-apoptosis protein: Survivin-derived peptide vaccine with and without interferon alpha therapy for patients with advanced or recurrent urothelial cancer-results from phase I clinical trials. Clin Dev Immunol. 2013;2013:262967.

109. Becker JC, Andersen MH, Hofmeister-Muller V, Wobser M, Frey L, Sandig C, Walter S, Singh-Jasuja H, Kampgen E, Opitz A, et al. Survivin-specific T-cell reactivity correlates with tumor response and patient survival: a phase-II peptide vaccination trial in metastatic melanoma. Cancer Immunol Immunother. 2012;61(11):2091-103.

110. Lennerz V, Gross S, Gallerani E, Sessa C, Mach N, Boehm S, Hess D, von Boehmer L, Knuth A, Ochsenbein AF, et al. Immunologic response to the Survivin-derived multi-epitope vaccine EMD640744 in patients with advanced solid tumors. Cancer Immunol Immunother. 2014;63(4):381-94.

111. Riedmann EM. Ovarian cancer vaccine candidate DPX-Survivac: positive interim results from phase 1. Hum Vaccin Immunother. 2012;8(12):1743.

112. Aarntzen EH, De Vries IJ, Lesterhuis WJ, Schuurhuis D, Jacobs JF, Bol K, Schreibelt G, Mus R, De Wilt JH, Haanen JB, et al. Targeting CD4(+) T-helper cells improves the induction of antitumor responses in dendritic cell-based vaccination. Cancer Res. 2013;73(1):19-29. 
113. Tanaka M, Butler MO, Ansen S, Imataki O, Berezovskaya A, Nadler LM, Hirano N. Induction of HLA-DP4-restricted anti-Survivin Th1 and Th2 responses using an artificial antigen-presenting cell. Clin Cancer Res. 2011;17(16):5392-401.

114. Widenmeyer M, Griesemann H, Stevanovic S, Feyerabend S, Klein R, Attig S, Hennenlotter J, Wernet D, Kuprash DV, Sazykin AY, et al. Promiscuous Survivin peptide induces robust CD4+ T-cell responses in the majority of vaccinated cancer patients. Int J Cancer. 2012;131(1):140-9.

115. Wang XF, Kerzerho J, Adotevi $O$, Nuyttens H, Badoual C, Munier G, Oudard S, Tu S, Tartour E, Maillere B. Comprehensive analysis of HLADR- and HLA-DP4-restricted CD4+ T cell response specific for the tumor-shared antigen Survivin in healthy donors and cancer patients. J Immunol. 2008;181(1):431-9.

116. Ohtake J, Ohkuri T, Togashi Y, Kitamura H, Okuno K, Nishimura T. Identification of novel helper epitope peptides of Survivin cancer-associated antigen applicable to developing helper/killer-hybrid epitope long peptide cancer vaccine. Immunol Lett. 2014;161(1):20-30.

117. Sharma RK, Yolcu ES, Srivastava AK, Shirwan H. CD4+ T cells play a critical role in the generation of primary and memory antitumor immune responses elicited by SA-4-1BBL and TAA-based vaccines in mouse tumor models. PLoS One. 2013;8(9):e73145.

118. Hoffmann PR, Panigada M, Soprana E, Terry F, Bandar IS, Napolitano A, Rose AH, Hoffmann FW, Ndhlovu LC, Belcaid M, et al. Preclinical development of HIvax: human Survivin highly immunogenic vaccines. Hum Vaccin Immunother. 2015;11(7):1585-95.

119. Rakshit S, Ponnusamy M, Papanna S, Saha B, Ahmed A, Nandi D. Immunotherapeutic efficacy of Mycobacterium indicus pranii in eliciting anti-tumor T cell responses: critical roles of IFNgamma. Int J Cancer. 2012;130(4):865-75

120. Kumar P, John V, Marathe S, Das G, Bhaskar S. Mycobacterium indicus pranii induces dendritic cell activation, survival, and Th1/Th17 polarization potential in a TLR-dependent manner. J Leukoc Biol. 2015;97(3):511-20.

121. Guo K, Tang JP, Tan CP, Wang H, Zeng Q. Monoclonal antibodies target intracellular PRL phosphatases to inhibit cancer metastases in mice. Cancer Biol Ther. 2008;7(5):750-7.

122. Guo K, Li J, Tang JP, Tan CP, Hong CW, Al-Aidaroos AQ, Varghese L, Huang C, Zeng Q. Targeting intracellular oncoproteins with antibody therapy or vaccination. Sci Transl Med. 2011;3(99):99ra85.

123. Hong CW, Zeng Q. Tapping the treasure of intracellular oncotargets with immunotherapy. FEBS Lett. 2014;588(2):350-5.

124. Rohayem J, Diestelkoetter P, Weigle B, Oehmichen A, Schmitz M, Mehlhorn J, Conrad K, Rieber EP. Antibody response to the tumor-associated inhibitor of apoptosis protein Survivin in cancer patients. Cancer Res. 2000;60(7):1815-7.

125. Nagaraj S, Pisarev V, Kinarsky L, Sherman S, Muro-Cacho C, Altieri DC, Gabrilovich DI. Dendritic cell-based full-length Survivin vaccine in treatment of experimental tumors. J Immunother. 2007;30(2):169-79.

126. Bertino P, Panigada M, Soprana E, Bianchi V, Bertilaccio S, Sanvito F, Rose AH, Yang H, Gaudino G, Hoffmann PR, et al. Fowlpox-based Survivin vaccination for malignant mesothelioma therapy. Int J Cancer. 2013;133(3):612-23

127. Srivastava AK, Sharma RK, Yolcu ES, Ulker V, MacLeod K, Dinc G, Shirwan $H$. Prime-boost vaccination with SA-4-1BBL costimulatory molecule and Survivin eradicates lung carcinoma in CD8+T and NK cell dependent manner. PLoS One. 2012;7(11):e48463.

128. Madireddi S, Schabowsky RH, Srivastava AK, Sharma RK, Yolcu ES, Shirwan H. SA-4-1BBL costimulation inhibits conversion of conventional CD4+ T cells into CD4+ FoxP3+T regulatory cells by production of IFN-gamma. PLoS One. 2012;7(8):e42459.

129. Ishizaki H, Manuel ER, Song GY, Srivastava T, Sun S, Diamond DJ, Ellenhorn JD. Modified vaccinia Ankara expressing Survivin combined with gemcitabine generates specific antitumor effects in a murine pancreatic carcinoma model. Cancer Immunol Immunother. 2011;60(1):99-109.

130. Xiang R, Mizutani N, Luo Y, Chiodoni C, Zhou H, Mizutani M, Ba Y, Becker JC, Reisfeld RA. A DNA vaccine targeting Survivin combines apoptosis with suppression of angiogenesis in lung tumor eradication. Cancer Res. 2005;65(2):553-61.

131. Kameshima H, Tsuruma T, Torigoe T, Takahashi A, Hirohashi Y, Tamura Y, Tsukahara T, Ichimiya S, Kanaseki T, Iwayama Y, et al. Immunogenic enhancement and clinical effect by type-I interferon of anti-apoptotic protein, Survivin-derived peptide vaccine, in advanced colorectal cancer patients. Cancer Sci. 2011;102(6):1181-7.

132. Berinstein NL, Karkada M, Oza AM, Odunsi K, Villella JA, Nemunaitis JJ, Morse MA, Pejovic T, Bentley J, Buyse M, et al. Survivin-targeted immunotherapy drives robust polyfunctional T cell generation and differentiation in advanced ovarian cancer patients. Oncoimmunology. 2015;4(8):e1026529.

133. Trepiakas R, Berntsen A, Hadrup SR, Bjorn J, Geertsen PF, Straten PT, Andersen $\mathrm{MH}$, Pedersen $\mathrm{AE}$, Soleimani A, Lorentzen T, et al. Vaccination with autologous dendritic cells pulsed with multiple tumor antigens for treatment of patients with malignant melanoma: results from a phase $\mathrm{l} /$ II trial. Cytotherapy. 2010;12(6):721-34.

134. Xiao M, Wang J, Lin Z, Lu Y, Li Z, White SW, Miller DD, Li W. Design, synthesis and structure-activity relationship studies of novel Survivin inhibitors with potent anti-proliferative properties. PLoS One. 2015;10(6):e0129807.

135. Xiao M, Li W. Recent advances on small-molecule Survivin inhibitors. Curr Med Chem. 2015;22(9):1136-46.

136. Nakahara T, Kita A, Yamanaka K, Mori M, Amino N, Takeuchi M, Tominaga F, Hatakeyama S, Kinoyama I, Matsuhisa A, et al. YM155, a novel small-molecule Survivin suppressant, induces regression of established human hormone-refractory prostate tumor xenografts. Cancer Res. 2007;67(17):8014-21.

137. Na YS, Yang SJ, Kim SM, Jung KA, Moon JH, Shin JS, Yoon DH, Hong YS, Ryu MH, Lee JL, et al. YM155 induces EGFR suppression in pancreatic cancer cells. PLOS One. 2012;7(6):e38625.

138. Giaccone G, Zatloukal P, Roubec J, Floor K, Musil J, Kuta M, van Klaveren RJ, Chaudhary S, Gunther A, Shamsili S. Multicenter phase Il trial of YM155, a small-molecule suppressor of Survivin, in patients with advanced, refractory, non-small-cell lung cancer. J Clin Oncol. 2009;27(27):4481-6

139. Chang CC, Heller JD, Kuo J, Huang RC. Tetra-O-methyl nordihydroguaiaretic acid induces growth arrest and cellular apoptosis by inhibiting Cdc2 and Survivin expression. Proc Natl Acad Sci USA. 2004;101(36):13239-44.

140. Khanna N, Dalby R, Tan M, Arnold S, Stern J, Frazer N. Phase I/II clinical safety studies of terameprocol vaginal ointment. Gynecol Oncol. 2007;107(3):554-62.

141. Shi X, Wang D, Ding K, Lu Z, Jin Y, Zhang J, Pan J. GDP366, a novel small molecule dual inhibitor of Survivin and Op18, induces cell growth inhibition, cellular senescence and mitotic catastrophe in human cancer cells. Cancer Biol Ther. 2010;9(8):640-50.

142. Ling X, Cao S, Cheng Q, Keefe JT, Rustum YM, Li F. A novel small molecule FL118 that selectively inhibits Survivin, Mcl-1, XIAP and CIAP2 in a p53-independent manner, shows superior antitumor activity. PLoS One. 2012;7(9):e45571.

143. Talbot DC, Ranson M, Davies J, Lahn M, Callies S, Andre V, Kadam S, Burgess M, Slapak C, Olsen AL, et al. Tumor Survivin is downregulated by the antisense oligonucleotide LY2181308: a proof-of-concept, firstin-human dose study. Clin Cancer Res. 2010;16(24):6150-8.

144. Choi KS, Lee TH, Jung MH. Ribozyme-mediated cleavage of the human Survivin mRNA and inhibition of antiapoptotic function of Survivin in MCF-7 cells. Cancer Gene Ther. 2003;10(2):87-95.

145. Karami H, Baradaran B, Esfahani A, Estiar MA, Naghavi-Behzad M, Sakhinia M, Sakhinia E. siRNA-mediated silencing of Survivin inhibits proliferation and enhances etoposide chemosensitivity in acute myeloid leukemia cells. Asian Pac J Cancer Prev. 2013;14(12):7719-24.

146. Paduano F, Villa R, Pennati M, Folini M, Binda M, Daidone MG, Zaffaroni $\mathrm{N}$. Silencing of Survivin gene by small interfering RNAs produces supra-additive growth suppression in combination with 17-allylamino17-demethoxygeldanamycin in human prostate cancer cells. Mol Cancer Ther. 2006;5(1):179-86.

147. Zhang R, Wang T, Li KN, Qin WW, Chen R, Wang K, Jia LT, Zhao J, Wen $\mathrm{WH}$, Meng $\mathrm{YL}$, et al. A Survivin double point mutant has potent inhibitory effect on the growth of hepatocellular cancer cells. Cancer Biol Ther. 2008;7(4):547-54.

148. Cheung $\mathrm{CH}$, Sun X, Kanwar JR, Bai JZ, Cheng L, Krissansen GW. A cellpermeable dominant-negative Survivin protein induces apoptosis and sensitizes prostate cancer cells to TNF-alpha therapy. Cancer Cell Int. 2010;10:36. 